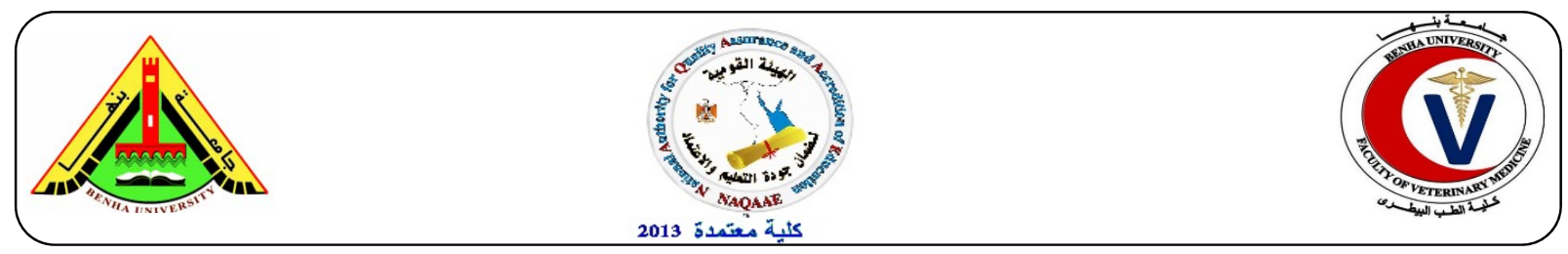

\title{
Clinical, hematological and biochemical changes in lambs suffered from nutritional muscular dystrophy
}

Ghanem, M.M., Anwar, M.R., Abd El-Raof, Y.M., El-Attar, H.M.

Animal Medicine Dept., Fac. Vet. Med., Benha University

\section{A B S T R A C T}

Nutritional Muscular Dystrophy (NMD) is a disease of lambs results from a selenium and/or vitamin E deficiency. This study was applied on $20 \mathrm{NMD}$ lambs and 20 control native breed lambs from Qalyubia Governorate, with ages ranged from 1 to 4 months, in order to explore the effects of NMD clinical and hematobiochemical changes in lambs. Affected lambs showed sternal recumbency, stiffness, trembling and muscle tremors, hard swollen muscle and the lamb adopted lateral recumbency. The diseased lambs had significant $(P<0.05)$ decreases in the serum Se and vitamin E. The RBCs count, $\mathrm{Hb}$ content and $\mathrm{PCV} \%$ were significantly decreased $(P<0.05)$ in NMD lambs. On other hand, the MCV and MCH were significantly increased $(P<0.05)$ in NMD lamb compared to control. The activities of ALT, AST, CPK, LDH and MDA were significantly increased $(P<0.05)$ in NMD lamb compared to control group. The SOD and GSH-Px were significantly decreased $(P<0.05)$ in NMD lamb compared to control. It was concluded that vitamin E and Se deficiency result in NMD which associated with alteration in clinical and hematological parameters.

Key words: Lamb, NMD, Selenium, Vitamin E.

(http://www.bvmj.bu.edu.eg)

(BVMJ-30(2): 61-66, 2016)

\section{1- INTRODUCTION}

Nutritional muscular dystrophy (NMD) is one of livestock disease associated with inadequate intake or utilization of vitamin E and Se (El-Neweehy et al., 2001). NMD is a peracute to subacute myodegenerative disease of cardiac and skeletal muscle (Or et al., 2003 and Smith, 2015). Ruminants appear to be more susceptible to the disease, with more severity in small ruminants (sheep and goats) (Ramirez et al., 2004, 2005). The affected animals exhibit muscular stiffness, arrhythmia, tachycardia and abdominal breathing (Hidiroglou et al. 1995). Furthermore, (Radostits et al. 2007) stated that recumbency, inability to stand, stiffness, trembling of the limbs, muscle tremors, dyspnea and abdominal breathing were the obvious signs in cases of NMD. In addition, lambs with 24 month of age are usually affected and may express goose-stepping gait due to muscular damage. (Fouda and Ibrahim, 1999). Hematological picture of affected lamb is characterized by changes in blood hemoglobin, $\mathrm{RBCs}, \mathrm{PCV}, \mathrm{MCV}$ and $\mathrm{MCH}$. These changes were related to Vitamin $\mathrm{E}$ and Se deficiency (Agag et al., 1995). Serum biochemical analysis of lambs with NMD is closely associated with changes in vitamin $\mathrm{E}$ and Se status. Different marker is commonly used to evaluate these changes such as glutathione peroxidase enzyme(GSH-PX), superoxide dismutase enzyme (SOD), creatine phosphokinase (CK), aspartate aminotransferase enzyme (AST), lactate dehydrogenase enzyme (LDH) and malondialdehyde (MDA) (EL-Deeb, 2010). Malondialdehyde (MDA) the product of polyunsaturated fatty acid oxygenation is a reliable and commonly used biomarker for assessing lipid peroxidation (Moore and Roberts, 1998). Recently, there has been growing interest in the use of MDA as a marker of lipid peroxidation in various kinds of diseases (Sheu et al., 2003). Therefore, this study was planned to assess the Clinical, hematological and biochemical changes of NMD in lambs.

\section{2-MATERIAL AND METHODS:}

\subsection{Animals:}

This study was undertaken on 40 lambs of both sexes with 1-4 months of age. The lambs were belonged to Mosthtohor Farm-production SectorAgriculture research center and teaching farm in faculty of veterinary medicine, Benha university Qalyubia Governorate. The lambs were classified 
according to clinical examination into the two groups: Group I: consists of 20 apparently clinically healthy lambs were kept as control where no clinical signs were demonstrated. Group II: consists of 20 lambs suffered from clinical signs of NMD. All animals were subjected to clinical examination including body temperature, pulse rate, respiratory rate in addition to observation to detect abnormal posture and gait (Radostits, 2007)

\section{2-2-Sampling:}

Blood samples were collected from jugular vein. The first set of blood samples were collected on labeled test tube containing $5 \mathrm{mg} \mathrm{k}_{2}$ EDTA in concentration of $1 \mathrm{mg} / 1 \mathrm{ml}$ blood (Coles, 1986) as an anticoagulant for determination of hematological parameters (total erythrocyte count, hemoglobin content, PCV). The second set of blood samples were collected without anticoagulant to separate and prepare serum samples into clear dry labeled Eppendorf tubes and stored at $-20^{\circ} \mathrm{C}$ for biochemical analysis. The third set of blood samples were collected with heparin for determination of erythrocyte GSH-PX activity in the RBCs lysate.

\section{2-3-Preparation of erythrocyte lysate:}

Erythrocyte lysate was obtained from centrifugation of the blood sample at $1000 \mathrm{rpm}$ for 10 minutes for separation of plasma. The erythrocytes were lysed in 4 times its volume of ice cold HPLC grade water centrifuged at 10,000 for 15 minutes at $4^{\circ} \mathrm{C}$. Then erythrocytes lysate was then collected and stored at $-80^{\circ} \mathrm{C}$ till analysis (Nishikimi et al., 1972).

\section{2-4-Biochemical analysis:}

Serum samples were used for determination of superoxide dismutase (SOD) according to the methods described by Beutler et al., (1963) using commercially available test kits supplied by Biodiagnostic, Egypt. Moreover, blood serum samples were subjected to the biochemical analysis for the determination of creatin phosphokinase (CK), aspartate amino transferase (AST) and lactate dehydrogenase (LDH) according to the methods described by Hare, (1950), Ritman and Frankel (1957) and Wroblewski et al., (1955), respectively, using commercially available test kits supplied by Biodiagnostic Egypt. Furthermore, the MDA levels were estimated using commercially available test kits supplied by Biodiagnostic Egypt according to the methods described by Satoh (1978) and Ohkawa et al. (1979). Se level was carried by atomic absorption spectrophotometer (wave length $136.03 \mathrm{~nm}$, Band path: $1.0 \mathrm{Um}$, lamb current 6.0mA. Flame "acetylene air" Air flow: 4.5 $\mathrm{ib} / \mathrm{inch}$ and gas pressure $2.1 \mathrm{ib} / \mathrm{inch}$ ) according to the method described by Fernadez and Kahr (1971). Alpha tocopherol (the active form of vitamin $\mathrm{E}$, was determined according to the method of Oser (1979) after extraction, saponification and re-extraction with organic solvents according to Hashim et al (1996).

\section{2-5-Statistical analysis:}

The data were statistically analyzed by T-test. We used SPSS version 16 software to conduct this analysis. Values were represented as means \pm standard error (SE). All differences were considered statistically significantly when $P<0.05$.

\section{3-RESULTS:}

\section{3-1-Clinical examination:}

Affected lamb were less than 4 months of age. Clinical examination of lambs of this group showed, ill thriftiness, weakness and depression, stiffness in gait, knuckling at fetlock joint (Fig .1), Sternal recumbency and unable to stand alone stand only with support and inability to stand but with obvious desire to stand in most cases (Fig .2). Stiffness, trembling and muscle tremors if the lambs were forced to stand, some lambs have lateral recumbency, dyspnea, and foamy nasal discharge. There was increase heart rate "tachycardia" and irregular heart beat "arrhythmia". There was significant increase in pulse rate in NMD affected lambs compared to control but no significant changes in body Temp. The body temperature was nearly normal but might be elevated above normal in some recumbent cases. The affected muscles (shoulder \& gluteal) felt hard, swollen and painful in palpation. (Table 1)

\section{3-2-Hematological examination:}

Table (2) showed that the RBCs count, $\mathrm{Hb}$ content and PCV\% were significantly decreased $(P<0.05)$ (in NMD lambs compared to control. On other hand, the MCV and $\mathrm{MCH}$ were significantly increased $(P<0.05)$ in NMD lamb compared to control.

\section{3-3-Biochemical analysis:}

Table (3) showed that Se and Vitamin E were significantly $(P<0.05)$ decreased in the serum of NMD lamb compared to control was significantly $(P<0.05)$ decrease of Vitamin $\mathrm{E}$ in serum of NMD lamb. Table (4) showed that the activities of ALT, AST, CK, LDH and MDA were significantly increased $(P<0.05)$ in NMD lamb compared to control group. The SOD and GSH-PX were 


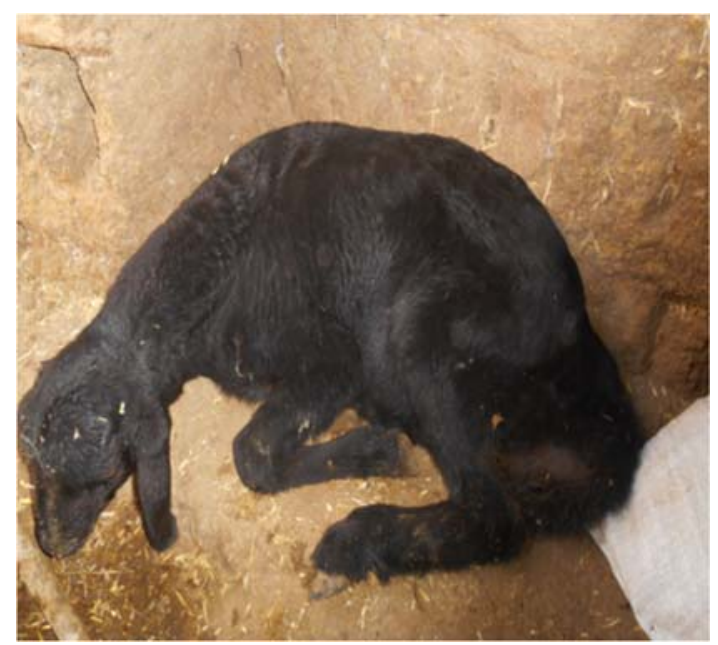

Fig (1): NMD lamb in sternal recumbency and unable to stand.

Table (1): Clinical parameters in control and NMD lamb:

\begin{tabular}{lll}
\hline \multicolumn{1}{c}{ Parameter } & Control & NMD lambs \\
\hline Body temperature & $39.2 \pm 0.17$ & $39.3 \pm 0.08$ \\
Respiration rate/minute & $23.66 \pm 1.2$ & $37.33 \pm 0.88^{*}$ \\
Pulse rate/minute & $81.0 \pm 1.52$ & $121.6 \pm 2.60^{*}$ \\
\hline
\end{tabular}

Table (2): Hematological picture of control and NMD lambs.

\begin{tabular}{lll}
\hline Parameter & Control & NMD lamb \\
\hline $\mathrm{Hb}(\mathrm{gm} / \mathrm{dl})$ & $9.87 \pm 0.12$ & $6.13 \pm 0.15^{*}$ \\
$\mathrm{RBCS}\left(10^{6} / \mathrm{CU} . \mathrm{mm}\right)$ & $10.68 \pm 0.15$ & $6.38 \pm 0.16^{*}$ \\
$\mathrm{PCV}(\%)$ & $33.1 \pm 0.12$ & $22.6 \pm 0.4^{*}$ \\
$\mathrm{MCV}(\mathrm{fl})$ & $18.3 \pm 0.26$ & $26.45 \pm 0.25^{*}$ \\
$\mathrm{MCH}(\mathrm{pg})$ & $23.3 \pm 0.26$ & $31.9 \pm .35^{*}$ \\
\hline
\end{tabular}

Table (3): Se, Vit. E level of control and NMD lambs

\begin{tabular}{lll}
\hline Parameter & Control & NMD lamb \\
\hline Selenium $(\mathrm{ppb})$ & $57.35 \pm 1.04$ & $18.8 \pm 0.52^{*}$ \\
Vitamin E $(\mu \mathrm{g} / \mathrm{dl})$ & $400.8 \pm 4.59$ & $141.4 \pm 3.38^{*}$ \\
\hline
\end{tabular}

Table (4): Selected biochemical parameters of control and NMD lamb:

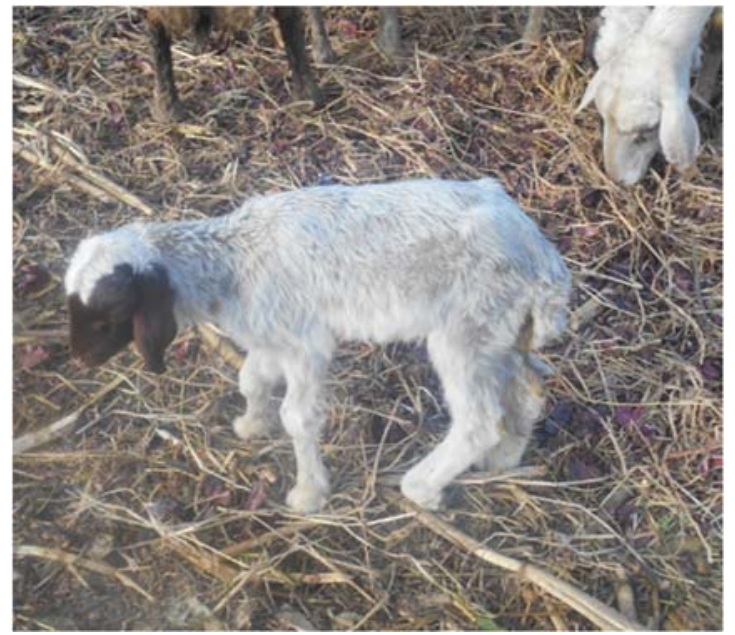

Fig (2): NMD lamb with knuckling at fetlock joint.

\begin{tabular}{lll}
\hline & Control & NMD lamb \\
Parameter & & \\
\hline ALT(U/L) & $9.92 \pm 0.19$ & $44.01 \pm 0.84^{*}$ \\
AST(U/L) & $59.95 \pm 0.1$ & $966.46 \pm 9.8^{*}$ \\
CK(U/L) & $46.35 \pm 1.12$ & $1143.39 \pm 16.56^{*}$ \\
GSH-Px (u/g & $7.96 \pm 0.17$ & $4.56 \pm 0.21^{*}$ \\
protein) & & \\
MDA(mmol/L) & $0.46 \pm 0.01$ & $1.64 \pm 0.01^{*}$ \\
SOD(mmol/L) & $1.60 \pm 0.035$ & $0.55 \pm 0.016^{*}$ \\
LDH(U/L) & $571.75 \pm 4.9$ & $1321.05 \pm 22.8^{*}$ \\
\hline
\end{tabular}

significantly decreased $(P<0.05)$ in NMD lamb compared to control.

\section{4-DISCUSSION:}

From our results concerning the clinical picture of NMD, the affected lambs showed sternal recumbency and inability to stand but with obvious desire to stand in most cases. Stiffness, trembling and muscle tremors occurred if the lambs were forced to stand, the affected muscles (usually shoulder \& gluteal) were hard and swollen and the lamb also showed lateral recumbency with inability to stand. In addition, there were polypnoea, frothy nasal discharge and tachycardia. These clinical changes could be attributed to the deficiency of vitamin $\mathrm{E} \&$ selenium which resulted in a wide spread of tissue lipoperoxidation that consequently led to hyaline degeneration of muscle fiber that make lamb recumbent and unable to stand (Or et al., 2003 and Smith, 2015). The increased respiratory rate and pulse rate (Table 1) could be attributed to affections of the respiratory muscles and heart muscle ((Radostits et al., 2007). The hematological examination (Tables 2) of the 
diseased lamb revealed anemia expressed as a significant decrease in $\mathrm{RBCs}$ count, $\mathrm{Hb}(\mathrm{gm} / \mathrm{dl})$ and PCV (\%). The anemia could be attributed to peroxidative damage of erythrocyte which occur secondary to alterations in cell membrane of erythrocytes due to deficiency of vitamin $\mathrm{E}$ and Selenium. It is well known that vitamin $\mathrm{E}$ is important component of cell membrane while selenium is important component of glutathione peroxidase enzyme in erythrocyte. This enzyme protects erythrocyte from free radical damage therefore their deficiencies lead to fragility and hemolysis. Se. is important for GSH-Px which protect cell from free radical which lead to peroxidative damage. Moreover, deficiency of vitamin $\mathrm{E}$ leads to abnormalities in bone marrow with subsequent abnormal hematological response (Radostits et al., 2007). Biochemically, the data presented at Table (3) demonstrated significant decrease in selenium level in serum of NMD lambs than control lambs. Se concentration in the serum is the most reliable method for screening the herd for selenium deficiency as selenium in blood is chemically stable than glutathione peroxidase and its concentration reflect long term selenium status of animal. (Mass, 1993). The data presented at Table (3) showed a significant decrease in alpha tocopherol in NMD than apparently healthy lamb. Serum level of alpha tocopherol $4 \mu \mathrm{g} / \mathrm{ml}$ considered as normal level of sheep. The critical level of serum alpha tocopherol is $2 \mu \mathrm{g} / \mathrm{ml}$ below which the deficiency disease occurs. (Radostits et al., 2007). With regard to Vitamin E level sheep is divided in to three categories, the first is deficient group in which vitamin E level in serum is lower than $150 \mathrm{mg} / \mathrm{ml}$, the second group is marginal group in which vitamin $\mathrm{E}$ level in serum in between 150 to $400 \mathrm{mg} / \mathrm{ml}$ and the normal sheep is more than $400 \mathrm{mg} / \mathrm{dl}$. (Smith, 2015). According to this classification all diseased lambs under investigation were considered as Vitamin E deficient lambs. The data presented at Tables (4) showed a significant increase in ALT, AST, CK, LDH and MDA level in serum of NMD lamb than control. However, there was a significant decrease in SOD, GSH-PX enzymes in NMD lamb than the control group. During normal cellular metabolism, the primary generation of reactive oxygen species comes from the leakage of superoxide anions from the electron transport chain. A series of linked enzymatic reactions are responsible for the detoxification of superoxide. Superoxide is converted to hydrogen peroxide by the action of superoxide dismutase (SOD). Hydrogen peroxide $\left(\mathrm{H}_{2} \mathrm{O}_{2}\right)$ is subsequently metabolized to oxygen and water by the selenium-containing enzyme glutathione peroxidase, which uses glutathione
(GSH) as a cofactor in the reaction. Therefor SOD is exhausted resulting in reduction of it's level (Glauser et al., 1999). Brown and Arthur (2001) and Surai (2006) stated that GSH-Px may be considered as a storage pool of Se because each GPx enzyme contains 4 Se-Cys residues Therefore, GSH-Px can be used as an indicator of Se status. In addition, GSH-Px plays an important role in providing protection against hydroperoxide damage. Therefore, Se deficiency is directly related to deficiency of GSH-Px. The MDA as a marker of lipid peroxidation in various kinds of diseases Sheu et al. (2003). Vitamin E is active within the cell membrane as a lipid-soluble antioxidant that scavenges free radicals that otherwise might react with unsaturated fatty acids to form lipid hydroperoxides (Smith, 2015). Vitamin E is a primary chain-breaking antioxidant that prevents cyclic propagation of lipid peroxidation (Finno, 2012). Therefore, the increased level of MDA can be attributed to increased lipid peroxidation that result from vitamin E deficiency. AST enzyme is increase in blood when there is damage in different organs such as muscle and liver. In NMD, damage to muscles usually occurs due to accumulation of free radicals as this free radical are removed from the body by action of GSH-PX and vitamin E. The deficiency of one or both lead to accumulation of free radicals in the body which lead to oxidative damage to cells which lead to allow of AST to pass blood barrier and its level increase in NMD lamb. therefore, AST enzyme is increased in muscle damage but the increase level of AST enzyme may also indicate liver damage (Radostits et al., 2007) can be used with other muscle specific enzymes to indicate muscle damage (El-Neweehy 2001 and Abood et al., 2012). The result of this study is also supported by Sobbiech and kutela (2002) and Mohri et al., (2011) who suggested that AST enzyme can be used as indicator for diagnosis of NMD in ruminant. The CK enzyme was increased significantly in lamb suffered from NMD. This could be attributed to myopathy caused by deficiency of selenium and vitamin E. (Fouda and Ibrahim, 1999; El-Neweehy et al., 2001 and ELDeeb, 2010). CK enzyme is considered the most sensitive bioindicator of muscle degeneration and show high affinity to muscle tissue (Kohli et al., 2005). It is considered as prognostic indicator of reduction in the myo-degeneration process as its level drop rapidly (Smith,2015) A permanent rise in CK activity is indicative of disease, and it is correlated with the degree of pathological change (Zarczyñska et al. 2012). LDH was enzyme significantly increased in lamb suffer from NMD due to dystrophic changes in muscular tissue 
(Zarczyñska et al., 2012; EL-Deeb, 2010). On the other hand, LDH is not specific to muscular tissue but also increase due to liver damage and digestive disorders (Sobiech and Kuleta,2006)

ALT enzyme was significantly increased in lambs suffered from NMD due to the dystrophic changes in muscular tissue (Agag et al., 1995; ELDeeb,2010 and Zarczyñska et al., 2012). The ALT is not specific to muscular tissue but also increase due to liver damage which may reported in lamb suffer from vitamin E deficiency (Abd-Elhamed, 2002).

\section{5-CONCLUSION}

It is concluded that serum Se and vitamin E levels are useful indicators for the diagnosis of NMD in lamb. Hematological examination of NMD lamb revealed anemia. Serum biochemical enzymes especially CK and LDH could be used as good markers for muscular damage caused by vitamin $\mathrm{E}$ and Se deficiency. GSH-Px activity is reliable indicator of Se deficiency in lambs. Therefore, it is very crucial to ensure adequate supplementation with Vitamin $\mathrm{E}$ and Se in the diet of sheep flock to avoid complication caused by NMD.

\section{6-REFERENCES}

Abd-Elhamed, E. 2002. Clinical and biochemical studies on vitamin $E$ and selenium deficiency in lambs. Ph.D.V.Sc. Thesis, Faculty of Vet. Med. Zagazig University.

Abood, H.K., Judi, A.M.H., AL-Ani, A.A. 2012. The effect of experimentally induced vitamin $\mathrm{E}$ and selenium deficiency on Creatine Kinase (CK) and Aspartate Aminotransferase (AST) activities in Awassi ewes and their newborn lambs. Kufa Journal for Veterinary Medical Sciences, 3(1): 132-137.

Agag, B.I., Nasser, M.H., Tawlik, A.M., Ragab, A.M., Mousa, S.H.M. 1995. Nutritional myopathy in weaner lamb. $3^{\text {rd }}$ Sci. cong. Egyptian Society for cattle Diseases, 3-5 Dec., Assuit, Egypt. Pp: 82-93.

Bailey, R.A. 2008. Design of Comparative Experiments. Cambridge University Press. Pp: 116-128.

Beutler, E., Duron, O., Kelly, M. 1963. Journal of Laboratory Clinical Medicine. Pp: 61:88.

Brown, K.M., Arthur, J.R. 2001. Selenium, selenoproteins and human health: a review. Public Health Nutrition 4: 593-599.

Coles, E.H. 1986. Veterinary clinical pathology. 4th Ed. W.B. Saunders Company,
Philadelphia, London and Toronto, Pp: 305326.

EL-Deeb, W.M. 2010. Ascorbate-glutathion affiliation and the treatment of nutritional muscular dystrophy in lambs with special reference to the oxidative stress, cercetări agronomice în moldova., 9(2): 76-88.

El-Neweehy, T.K., Abdel-Rahman, H.A., AlQarawi, A.A. 2001. Some studies on nutritional muscular dystrophy in Qassim region in Saudi Arabia. Effect of administration of Vitamin E-selenium preparation to pregnant ewes on serum muscle-specific enzymes in their lambs. Small Ruminant Research ,41: 87-89.

Fernadez, J., Kahr, H. 1971. Clinical methods for atomic absorption spechoscopy. Clinical Chemistry Newest., 3:124.

Finno, C.J., Valberg, S.J. 2012. A comparative review of vitamin $\mathrm{E}$ and associated equine disorders, J Vet Intern Med, 26, Pp: 12511266

Fouda, T.A., Ibrahim, T.M.1999. Concurrent nutritional muscular dystrophy and zinc responsive parakeratosis in lamb. Alex. J.Vet. Sci., 15: 909-920.

Glauser, T.A., Titanic-Schefft, M., Pippenger, C.E. 1999. Racial differences in free radical scavenging enzyme activity in children. J. Child Neurol. 14: 382-387.

Hare, R.S. 1950. Endogenous creatinine in serum and urine. Proceeding of the Society for Experimental Biology and Medicine. 74: 148-511.

Hashim, I.B., Koehler, P.E., Eitenmiller, R.R., Kuien, C.K.1996. Fatty acid composition and tocopherol content of drought stressed florunner Peanuts. Peanuts Science 20: 2124.

Hidiroglou, M., Batra, T., Ivan, M., Markham, F. 1995. Effects of supplemental vitamins $\mathrm{E}$ and $\mathrm{C}$ on the immune response of calves. Journal of Dairy Science. 78: 1578-1583.

Kohli, R., Harris, D.C., Whitington, P.F. 2005. Relative elevation of serum alanine and aspartate aminotransferase in muscular dystrophy. J Pediatr Gastroenterol Nutr., 41: 121-124.

Maas, J. 1990. Trace element deficiencies: Diagnosis, treatment and prevention. Sponsored by Schering/Plough animal health at theXV1 world Buiatrics Congress, August, 13 to 17, Salvador, Bahia, Brazil.

Mohri, M., Abdollah, E., Norouzian, M. A., Mohammad, H.B., Hesam, A.S. 2011. Parenteral Selenium and Vitamin E Supplementation to Lambs: Hematology, 
Serum Biochemistry, Performance, and Relationship with Other Trace Elements. Biol Trace Elem Res. 139: 308-316.

Moore, K., Roberts, L.J. 1998. Measurement of lipid peroxidation. Free Radic Res., 28: 659671.

Nishikimi, M., Appaji, N., Yagi, K. 1972. The occurrence of superoxide anion in the reaction of reduced phenazine methosulfate and molecular oxygen. Biochemical and Biophysical Research. Communication, 46: 849-54.

Ohkawa, H., Ohishi, W., Yagi, K. 1979. Analytical Biochemistry. 95:351.

Or, M.E., Dodurka, T., Kayar, A. 2003.The diagnostic importance of erythrocyte peroxidase (GSH-Px) activity and some serum parameters in lambs with white muscle disease. Turk J Vet Anim Sci, 27: 16.

Oser, B.l. 1979. Hawks physiological chemistry. $14^{\text {th }}$ Ed. Tata McGraw-Hill. Publishing Company Ltd. New Delhy.

Radostits, O.M., Gay, C.C., Hinchcliff, K.W., Constable, P.D.2007. Veterinary Medicine, A Textbook of the Diseases of Cattle, Horses, Sheep, Pigs and Goats, 10th edition. WB Saunders/Elsevier, Pp: 1735-1755.

Ramirez, B.E., Hernandez, C.E., Hernandez, C.L.M., Tortora, P.J.L. 2004. Effect of parenteral supplement with sodium selenite on lamb mortality and hematic values of selenium. Agrociencia, 38:43-51.

Ramírez, B.E., Tórtora, J.L., Huerta, M., Hernández, L.M., López, R., Crosby, M. 2005. Effect of selenium-vitamin E injection in selenium-deficient dairy goats and kids on the Mexican plateau. Arq. Bras. Med. Vet.Zootec., 57: 77-84.
Reitman, S., Frankel, S. 1957. Colorimetric determination of GOT and GPT activity. American Journal of Clinical Pathology. Pp: 28- 56.

Satoh, K. 1978. Serum lipid peroxide in cerebrovascular disorders determined by a new colorimetric method. Clinica Chemica Acta., 90(1):37-43.

Sheu, J., Ku, H., Tseng, W., Chen, M., Tsai, L., Huang, Y. 2003. Determination of thiobarbituric acid adduct of Malondialdehyde using on-line microdialysis coupled with high performance liquid chromatography. Analytical Science. 19: 621-624.

Smith, B.P. 2015. Large Animal Internal Medicine $.5^{\text {th }}$ Ed. Portland, Oregon, Mosby publishing.

Sobbiech, P., Kuleta, Z. 2002. Usefulness of some biochemical indicators in the detection of early stages of nutritional muscular dystrophy in lambs. Small animal research, 45: 209-215.

Sobiech, P., Kuleta, Z. 2006. Activity of LDH isoenzymes in diarrhoeic calves. Bull Vet Inst Pulawy 50: 401-404.

Surai, P. 2006. Selenium in nutrition and health. Nottingham University Press Nottingham, United Kingdom.

Wroblewski, V.F., Duean, L.1955. Serum Lactic Dehydrogenase Activity in Acute Transmural Myocardial Infarction, Proceedings of the Society for Experimental Biology and Medicine 90: 210-214.

Zarczyñska, K., Sobiech, P., Pomianowski. A., Waclawska, A., Stopyra, A., Illek, J. 2012. Changes of selected biochemical indicators and electrocardiography indicators in nutritional muscular dystrophy in calves. Acta vet. Brno 81: 119. 